Zoologica Poloniae (2009-2010) 54-55/1-4: 43-58

DOI: $10.2478 / \mathrm{v} 10049-010-0005-\mathrm{z}$

\title{
EPIMORPHOSIS OF HETEROSYMELIC APPENDAGES IN TEGENARIA ATRICA (ARANEAE, AGELENIDAE)
}

\author{
Teresa NApiórkowska, Lech JaCuński and Julita Templin
}

Department of Invertebrate Zoology, Institute of General and Molecular Biology, Nicolaus Copernicus University, Gagarina 9, 87-100 Toruń, Poland e-mail: tnapiork@biol.uni.torun.pl

\begin{abstract}
Studies of epimorphic regeneration of appendages were carried out on larvae and nymphs of Tegenaria atrica C.L.KocH with heterosymely (accretion of appendages on the same side of the body) of two walking appendages and of walking appendages with pedipalpi. All the anomalies were obtained by exposing developing embryos to alternate temperatures of 14 and $32^{\circ} \mathrm{C}$. Amputation of fragments of anomalous appendages was always followed by regeneration. Based on the characteristic external structures of the regenerating joints, successive stages of epimorphosis were estabilished, whose start and end were marked by ecdyses. Several types of regenerates were found, whose anatomical structure did not undergo further significant changes until the end of our observations.
\end{abstract}

\section{INTRODUCTION}

Epimorphic regeneration of appendages, one of the arthropods' most important achievements, has been best investigated in Crustacea and Insecta (e.g., Agar, 1930; Penzlin, 1963; Needham, 1965; Goss, 1969; Edwards, 1972; Bittner, 1973; Founier, 1973; Mc Vean, 1976; Hopkins, 1982, 1993, 1995, 2001; Reichmann, 1984; Mohrherr, 1987; Lakes and Mücke, 1989; Smith, 1990, 1992; Lumb at al., 1991; Clare at al., 1992; Demeusy, 1995; Junnes and Smith, 1995; Brock and Smith, 1998; Cooper, 1998; Read and Govind, 1998; Mykles, 2001). There are much fewer publications concerning epimorphosis in Araneae. The fundamental and undoubtedly most extensive study concerning this phenomenon in spiders was published as early as in 1930 by BONNET. The author discussed extensively and in great detail the phenomenon of regenerating lost appendages and other 
morphological structures, the most interesting and pioneering observations being those concerning post-autotomic regeneration of appendages in Dolomedes. BonNet (1930) paid special attention to the time and place of the development of such regenerates, their structure and equipment with structures of cuticular origin. He also described changes which take place in regenerated appendages after consecutive ecdyses. BONNET also studied post-injury epimorphosis of appendages. After removing various fragments of appendages he obtained their regeneration irrespective of the location of the tomy and he demonstrated the possibility of including regeneration of appendages after simultaneous amputation of several appendages.

BONNET's work, however, was not the first study of autotomy and regeneration in spiders. Earlier publications were those by FrIEDRICH (1906), WeISS (1907), Oppenheim (1908) and Wood (1926). Particularly noteworthy are the reports of Friedrich (1906) and those of Oppenheim (1908), whose results differed significantly from those described by BonNET. Autotomy, ordinary tomy and the capacity for regeneration in spiders were also the subject of study of many other arachnologists (GABRITSCHEVSKY, 1927, 1930; LoCKet, 1936; SAVORY, 1936; Mikulska et al., 1975; Ruhland, 1976; Randal, 1981; Rотн and Roth, 1984; Vollrath, 1990), who observed interesting relationships between those processes. It turned out that some spiders, such as Araneus diadematus (CLERCK), Argiope argentata (FABricius), Cyrtophora moluccensis (DolesChall), Tegenaria atrica C.L.Koch or Dolomedes fimbriatus (CLERCK), regenerate their appendages amputated at different places as successfully as those cut off at the articulations between the coxa and the trochanter. On the other hand, Nephila claviceps (L.), Zygiella $x$ - notata (CLERCK), Latrodectus mactans (FABRICIUS) are incapable of regenerating their appendages between the coxa and the trochanter but the process takes place in other, more distal parts of the legs.

Research on appendage regeneration was also conducted by the French arachnologist VACHON (1967). His experiments on appendage regeneration of Coelotes terrestris (WIDER, 1834) confirmed the opinion that amputation induces a reinitation of the morphogenetic processes which took place earlier in appendages development during embryogenesis and early postembryogenesis. Based on those observations, he distinguished four stages in the regenerate's development: the embryonic, the prelarval, the larval and the nymphal stage. According to that researcher, the development of a given type of regenerate depended directly the time of amputation. Finally, thorough studies of each regenerated joint induced the author to adopt the hypothesis of heterogeneity of the regenerates, as they consisted of joints of different ages, the most distal ones being the oldest.

It follows from the above that "normally" developed spider appendages successfully undergo epimorphic regeneration, and that process has been fairly well explored. The regeneration effect in appendages with a modified structure, however, is still unknown. It is known that exposure of developing embryos to teratogenic factors may result in all sorts of disturbances, which in the postembryonic stage leads, among other things, to heterosymely (complete or partial 
coadunation of two neighbouring legs). Reports concerning epimorphosis and the possibility of an idiopathic repair mechanism working in such cases are but fragmentary (MiKULSKA and JACUŃSKi, 1977; JACUŃSKI and NAPIÓRKowSKA, 2000; JACUŃSKI at al., 2002). It thus seemed important to expend and complete information on regeneration in the aspect of that development deformity, considering that besides the obvious anatomical disturbances there may also occur disturbances in the morphogenic processes (JACUŃSKI, 1983).

\section{MATERIAL AND METHODS}

Experimental studies were carried out on larvae and nymphs of T. atrica (Agelenidae). Particular development stages of that species were defined according to the terminology adopted by VACHON (1957). The experimental part of the study consisted of two stages: in the first one larvae with heterosymely were obtained, in the second one amputation was carried out and the regeneration process was observed.

The experimental work, continued for several years, was preceded each year by setting up a laboratory culture. For that purpose in the summer months of 1996-2002, sexually mature T. atrica individuals were systematically captured and then kept in the laboratory. The culture was run at a temperature of $21-23^{\circ} \mathrm{C}$ and ca $70 \%$ relative humidity. The room were the spiders were kept, each individual in a glass jar of $250 \mathrm{~cm}^{3}$ in capacity, was properly shaded. The spiders were fed twice a week on Tenebrio molitor L., and Acheta domesticus L., larvae. After a fortnight of adaptation each female was kept for several hours with different males in succession in order to obtain full insemination. After oviposition the eggs were exposed alternately to temperatures of $14^{\circ} \mathrm{C}$ and $32^{\circ} \mathrm{C}$. The temperatures were changed every 12 hours for 10 days, i.e., from the moment of oviposition to that of the formation of the first metameres of the prosoma on the germ band. Then the developing embryos were kept at a temperature of $23^{\circ} \mathrm{C}$ until they threw off the egg chorion and prelarval membrane. For further studies of regeneration we selected larvae with partial heterosymely of walking legs and those with partial heterosymely of walking and feeding appendages. Considering the small size of the larvae, the amputation by means of a nylon thread ligature was carried out under a stereoscopic microscope.

Then each operated individual was placed separately in a glass dish, were it stayed through the successive postembryonic stages until the end of the observation. In order to secure the ligatured and regenerating appendages against autotomy, which could distort the methodical principles of the experiments, every day the web was removed from the dishes. That operation, drastic for the spiders' behaviour, prevented the danger of the ligatured appendage getting knotted in the web, which would most probably result in the whole appendage being torn off.

Throughout the duration of the experiment the individuals under study were regularly fed, starting from I stage nymph, first on newly deposited spider eggs, then on small Tribolium sp. and T. molitor L. larvae. Drinking water was 
supplied by means of a cotton wool ball soaked with water. At the same time, under similar experimental conditions a control culture was run, consisting of individuals which developed the same deformity of prosomal appendages as that in individuals subject to observation of the regeneration process. Photographs were taken of all the individuals in the successive phases of the experiment.

\section{RESULTS}

In the first phase of the experiment ca 15 thousand embryos were exposed to alternate temperatures $\left(14\right.$ and $\left.32^{\circ} \mathrm{C}\right)$. By that embryogeny disturbing method a total of 129 heterosymelic individuals were obtained. More than half of them (72) showed partial accretion of walking legs. The most numerous (ca $89 \%$ ) were individuals in which accretion extended from the coxa to the femur or the patella, and in some cases to the tibia inclusive. Only two larvae were characterized by a deeper anomaly approaching total heterosymely. In the remaining heterosymelic larvae (56) that anomaly consisted in partial or complete accretion of the first walking leg and the pedipalpus, and in one of individual there appeared complete heterosymely of the chelicera and the pedipalpus.

a) regeneration in case of heterosymely of the walking appendages

The experiment researching epimorphosis of heterosymelic walking appendages was carried out in two variants. Each of them started with the amputation of appendages, which took place on the second day after the larva's hatching from eggs. In the first variant ( 29 individuals) the study concerned the capability for regeneration of one of the two free endings of a heterosymelic appendage. The place of amputation was in direct vicinity of the accreted part of the two legs (Fig. 1). In the other variant (27 individuals) much larger fragments of the heterosymelic appendages were amputated. The nylon thread ligatures were placed at mid-length of the accrete femur joints, which resulted in the detachment of the corresponding parts of the accrete legs together with their free endings (Fig. 2).

The tightening of the ligature broke the continuity of the epithelium secreting the exoskeleton and of the muscles and nerves running along the appendages and it also effectively closed the hemocoel. The wound under the ligature scabbed, which ensured bloodless casting off of the dead part of the appendage in the course of the nearest ecdysis. After casting off the exuvium all the individuals showed well scabbed wounds at the place of the tomy. Their surfaces were very differently shaped depending mainly on the diameter of the appendage at the place where the ligature was put. In cases when tomy was applied only to the free fragments of a heterosymelic appendage with diameters of properly formed appendages the post-injury scars were flat or slightly protuberant. Sporadically there appeared on them small bulges in the form of nodules (Fig. 3). When the ligatures were applied at mid-length of coadunate 
femora with comparatively large diameters, amputation resulted in the formation of a very extensive, strongly cuticularized scar with numerous irregularities, mainly in the form of nodules or small cuticular cones (Fig. 4).

In both variants of the experiment the regenerates appeared only after the second post-larval moult following the application of the ligature, i.e. in individuals in nymph II stage. After amputation of one free ending of heterosymelic appendages all the first regenerates (in 22 individuals which survived the operation and reached nymph $\mathrm{V}$ stage when the experiment was ended) were comparatively short. Their lengths together with the remaining part of the appendage reached ca $67 \%$ length of a properly developed walking leg. The regenerates were covered with transparent cuticle devoid of pigment, through which directly after ecdysis hemolymph could be seen circulating in the microcoel. On their surface were found sparse, very short cuticular setae. Moreover, between all the regenerated joins could be seen articulate surfaces (Fig. 5). Further growth and development of the regenerates were observed starting from nymph II until nymph V stage, when the experiment was ended. In nymph III stage they reached as much as $92 \%$ length of their sister walking appendage. At the stage there were many more setae on the cuticle of all the joints of the regenerates
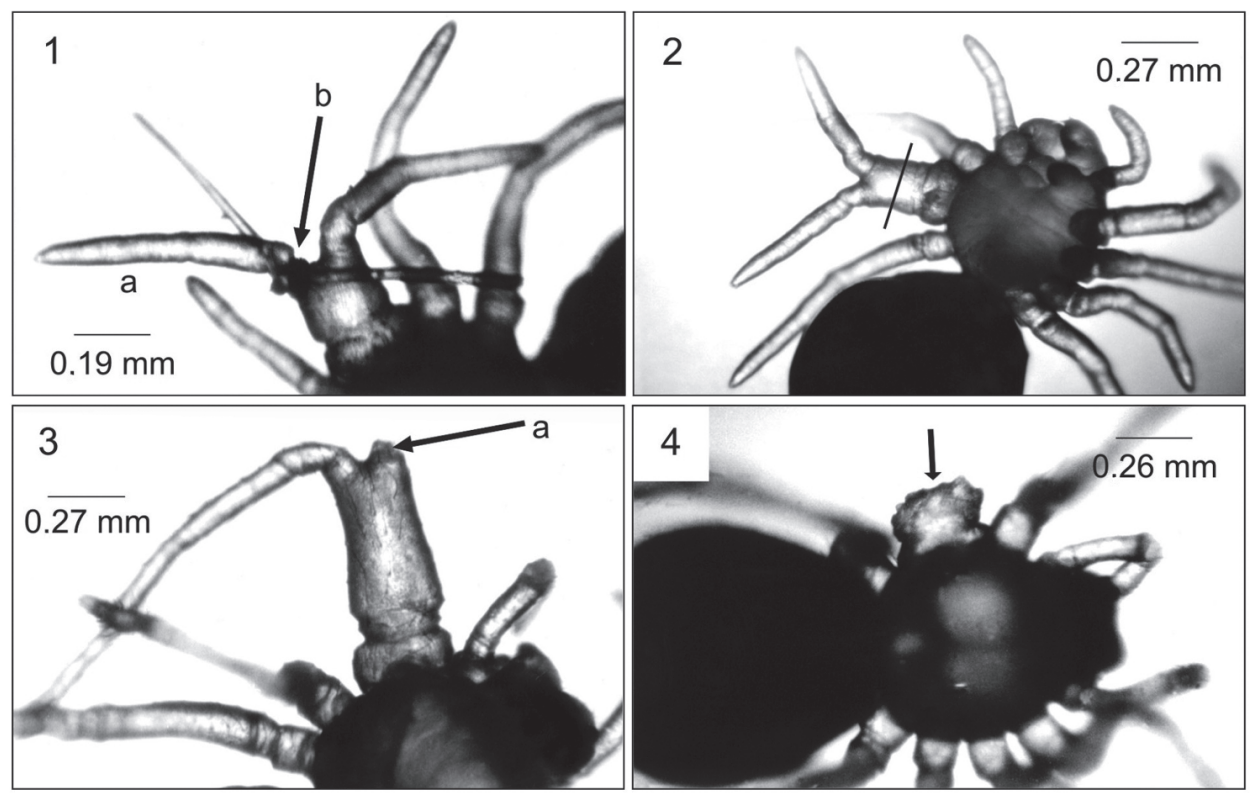

Figs 1-4. 1 - Tegenaria atrica C.L.Koch larva with ligature on one free ending of heterosymelic appendage: $\mathrm{a}$ - free ending of heterosymelic appendage, $\mathrm{b}$ - ligature; 2 - Tegenaria atrica C.L.Koch with marked place of ligature aplication; 3 - Tegenaria atrica C.L.Koch nymph I after amputation of a free ending of heterosymelic appendage: a - place of amputation; 4 - Tegenaria atrica C.L.Koch nymph I after amputation of heterosymelic appendage; scar with irregularities. 
than in the previous development phase and they were longer. At the end of the tarsus there appeared two archwise bent dentate claws. Further elongation of the regenerates followed in nymphs IV, when they reached ca $97 \%$ length of the leg of the other leg of the pair. At that time they had various densely set setae, trichobothria and a much better developed set of claws. The regeneration process ended in individuals in nymph V stage (after five post-larval moults)(Table 1).

In the second variant of the experiment, out of 27 larvae with ligatures squeezed at mid-length of their accreted femora external regenerates were observed in only 15 individuals which survived until nymph V stage. There were two kinds of them. In eight spiders epimorphic processes resulted in the development of a homogeneous regenerate with no trace of bifurcation in its distal part. It was in those cases that the anomaly was the deepest. Partial heterosymely turned into complete heterosymely (Fig. 6). In the remaining seven spiders the regenerate had two free endings of the same length and with the same number of joints (Fig. 7). Based on the morphological structure of the regenerates it was found that the anomaly in those cases became even deeper, since the regenerating appendages were always accreted over a longer section than before, in the larval stage. Both kinds of the first regenerate were characterized by a light pigmentless cuticle with scattered very small setae. The appendages together with the regenerates were on average by ca $58 \%$ shorter than their sister ap-
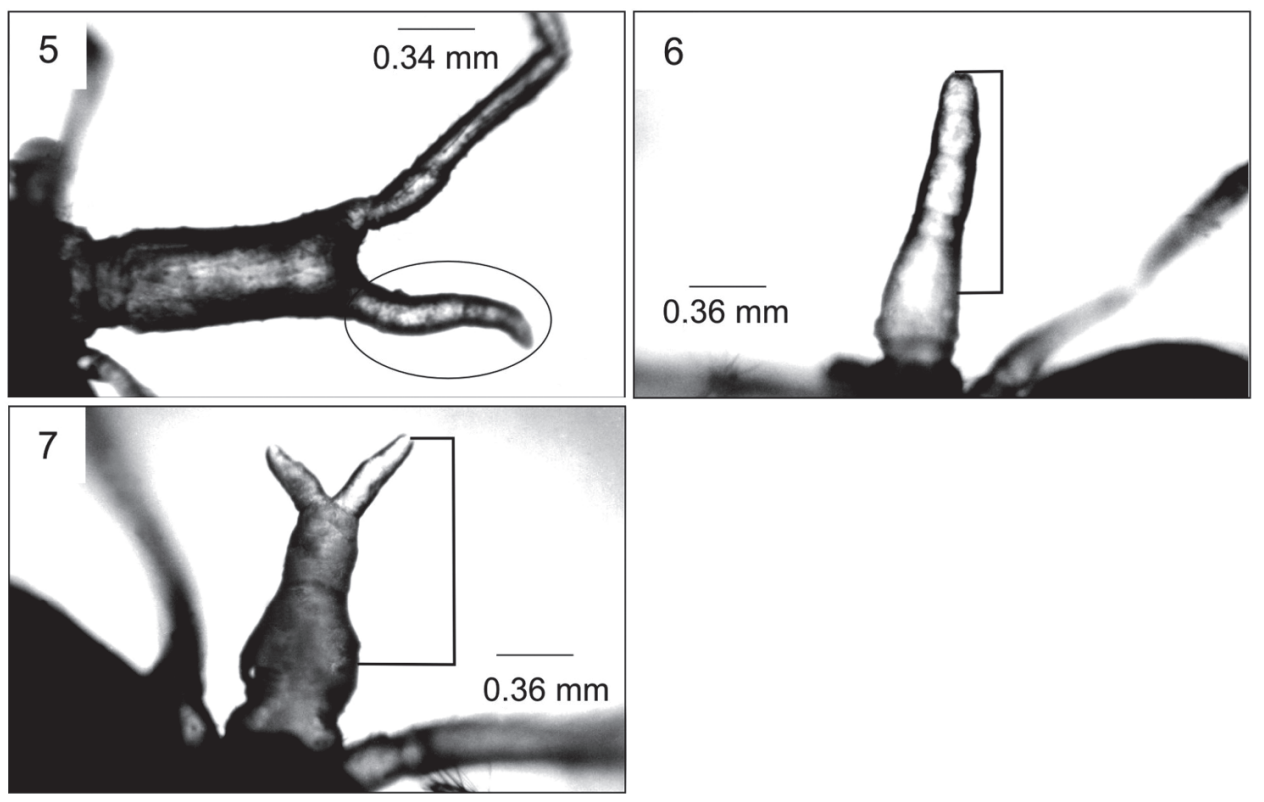

Figs 5-7. 5 - Tegenaria atrica C.L.KocH nymph II with first regenerate of free ending of heterosymelic appendage; 6 - Uniform first regenerate after amputation of heterosymelic appendage; 7 - Regenerate with two free endings in nymph II after amputation of heterosymelic appendage. 
Table 1

Mean lengths of legs with normal anatomical structure and of regenerating heterosymelic legs after amputation at larval stage (variant I).

\begin{tabular}{|c|c|c|c|}
\hline \multirow{2}{*}{ Development stage } & \multicolumn{2}{|c|}{$\begin{array}{c}\text { Mean lengths (mm) of walking legs } \\
\text { during epimorphosis }\end{array}$} & \multirow{2}{*}{$\begin{array}{l}\text { Ratio of lengths of } \\
\text { heterosymelic legs } \\
\text { with regenerates to } \\
\text { that of normal leg in } \%\end{array}$} \\
\hline & $\begin{array}{l}\text { With normal } \\
\text { anatomical structure }\end{array}$ & $\begin{array}{c}\text { Heterosymelic } \\
\text { with regenerates }\end{array}$ & \\
\hline Larva & 1.62 & \multirow{2}{*}{\multicolumn{2}{|c|}{$\begin{array}{l}\text { Amputation } \\
\text { No regenerate }\end{array}$}} \\
\hline N I & 2.72 & & \\
\hline N II & 4.27 & 2.86 & 66.98 \\
\hline N III & 5.09 & 4.66 & 91.55 \\
\hline N IV & 6.24 & 6.04 & 96.79 \\
\hline $\mathrm{N} \mathrm{V}$ & 8.13 & 8.10 & 99.63 \\
\hline
\end{tabular}

pendages on the other side of the prosoma. They elongated only after the following ecdysis in nymph III stage. This time they reached ca $55 \%$ length of the corresponding appendages on the other side of the prosoma. There were more setae on the regenerates and they were longer. The heterosymelic appendages with their regenerates continued to elongate, reaching ca $63 \%$ length of the properly developing walking legs in nymph IV stage, and 65\% in nymph $\mathrm{V}$ (Table 2). The arrangement and shape of the claws were characteristic of each of the above two types of regenerates. In the first type, where the free endings had disappeared, there were two full sets of claws at the tip of the "double" tarsus (Fig. 8). In only one individual there was no full equipment of the tarsus. In the other kind of epimorphic regenerate there were usually claws normal for Tegenaria on both free endings. Deformities of that equipment were very rare (Fig. 9). Throughout the experiment the heterosymelic appendages together with

Table 2

Mean lengths of legs with normal anatomical structure and of regenerating heterosymelic legs after amputation at larval stage (variant II).

\begin{tabular}{cccc}
\hline \multirow{2}{*}{ Development stage } & \multicolumn{2}{c}{$\begin{array}{c}\text { Mean lengths (mm) of walking legs } \\
\text { during epimorphosis }\end{array}$} & $\begin{array}{c}\text { Ratio of lengths of } \\
\text { heterosymelic legs } \\
\text { with regenerates to }\end{array}$ \\
\cline { 2 - 3 } & $\begin{array}{c}\text { With normal } \\
\text { anatomical structure }\end{array}$ & $\begin{array}{c}\text { Heterosymelic } \\
\text { with regenerates }\end{array}$ & \multicolumn{2}{c}{$\begin{array}{c}\text { Amputation } \\
\text { that of normal leg in \% }\end{array}$} \\
\hline Larva & 1.62 & \multicolumn{2}{c}{ No regenerate } \\
N I & 2.74 & 1.82 & 42.37 \\
N II & 4.30 & 2.83 & 55.06 \\
N III & 5.14 & 3.97 & 62.81 \\
N IV & 6.32 & 5.37 & 64.85 \\
N V & 8.28 & &
\end{tabular}




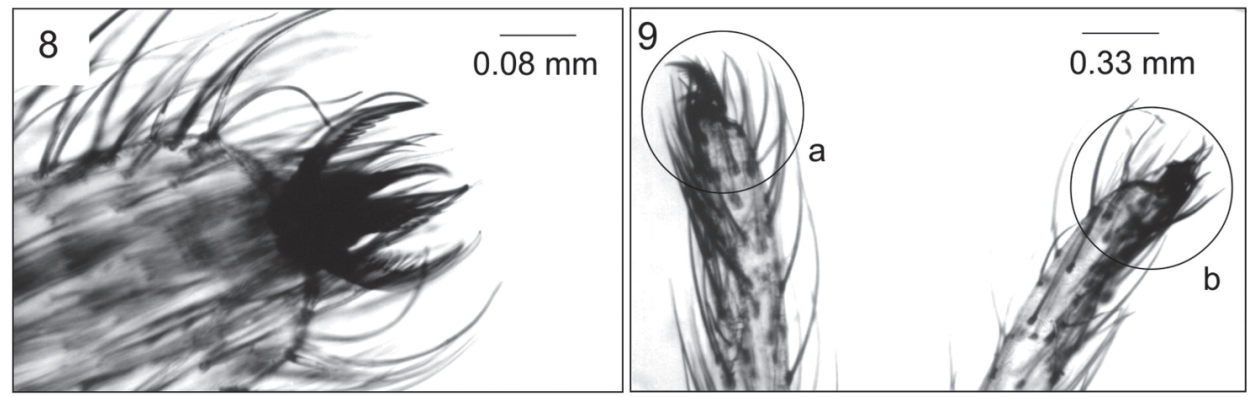

Figs 8-9. 8 - Equipment of distal part of heterosymelic regenerate in nymph V; 9 - Claws on tarsi of regenerate with partial heterosymely in nymph V: a - normally developed set of claws, b - deformed set of claws.

their regenerates were rigid in all their articulations. They were often bent archwise, the bend becoming deeper after each moult. Such appendages never served for locomotion.

Seven individuals with partial heterosymely were treated as control sample. Observations were carried out of their further development, their way of moving and other vital functions. The degree of appendage deformity in those individuals varied. The free endings of the complexes were characterized by full jointing and comparatively low mobility. With each ecdysis they underwent developmental changes like other prosomal walking appendages. They grew in length, trichobothria and various setae appeared on them, and sets of claws developed on the free endings. It seems important that the degree of the deformity remained the same throughout the experiment (Figs 10, 11). Neither deepening nor recession of the deformity that appeared during embryonic development was observed. Those appendages were not used by the spiders but because of the absence of web they also were not torn off at the place of autotomy.
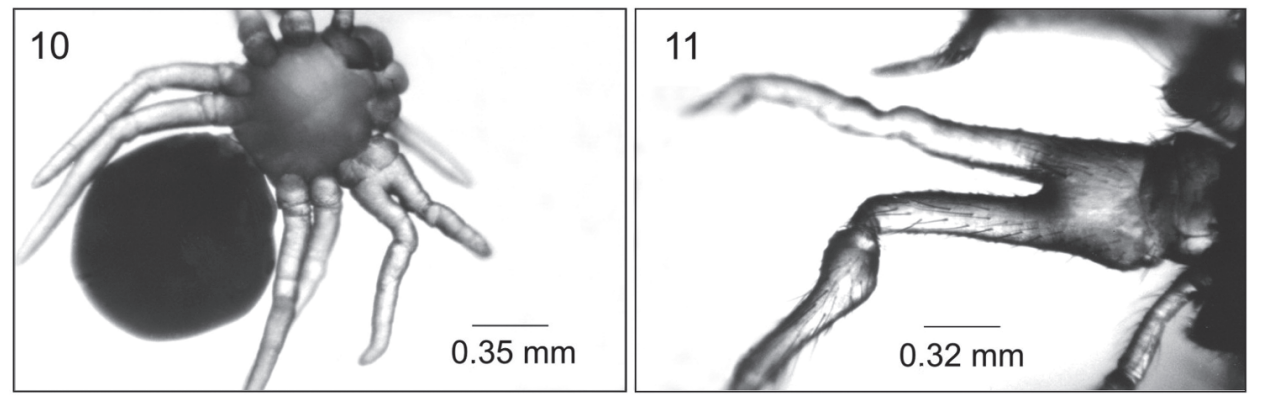

Figs 10-11. 10 - Tegenaria atrica C.L.Koch larva with partial heterosymely of walking appendages; 11 - Heterosymely of walking appendages in individual from Fig. 10 . 
Not all individuals undergoing regeneration reached the nymphal stage at which the experiment was ended. The mortality among spiders in that series of experiments averaged $34 \%$. A higher percentage was noted in the second variant (ca 44\% - 12 individuals), a lower one (ca 24\% - 7 individuals) in the first variant of the experiment. The causes of death varied widely. In the first place they resulted from difficulties with moulting. However, in the control sample all the individuals lived until the completion of the experiment reaching nymph $\mathrm{V}$ stage.

b. regeneration in case of heterosymely of a walking appendage and a pedipalpus

For this part of the experiment 53 larvae were selected with heterosymely of the pedipalpus and the first walking appendage. Among them were individuals with complete and with partial heterosymely. The first kind of deformity occurred in only 11 individuals, the second one in the remaining 42. The length of the accreted appendages depended on the kind of anomaly. In partial heterosymely, where accretion included the first three or at most four joints, the appendages retained the length of properly developed legs, while in complete heterosymely the appendage complex that formed was bent archwise towards the front of the body and was shorter. On its surface there were folds in the form of rings, the consequence of which was complete effacement of jointing, particularly in the distal part. Such appendage complex showed very low mobility.

Out of 53 larvae selected from among the teratological material, in 42 individuals the legs were amputated by squeezing ligatures at mid-length of coadunate femur joints (Fig. 12). Among them were eight larvae with complete and 37 with partial heterosymely. The remaining eight larvae constituted the control sample.

In nymphs $\mathrm{I}$ at the place of the tomy variously formed scars were observed. On a vast flat or sometimes bulging surface there were all sorts of irregularities in the form of nodules or more intensely cuticularized plates. After the following moult, i.e. in nymphs II (after two post-larval moults) there appeared regenerates, which clearly differed both from the "old" part of the complex and from the remaining prosomal appendages. The cuticle on the regenerates was light with sparse short setae. The regenerating parts of the legs had markedly smaller diameters, and the articulate surfaces between the distal joints could hardly bee seen. From the moment that the first regenerates appeared it was noted that they always assumed a curved shape. Another very characteristic feature of the regenerates was the morphological structure of their distal parts. Regardless the character of the deformity occurring in the larva (complete or partial heterosymely), the regenerated joints of both appendages were never completely accreted. In their distal parts there were always two, sometimes deformed, free endings of different lengths (Fig. 13). Comparing the degree of the original deformity with that in nymphs II it was found that in the case of complete heterosymely there occurred a slight "shallowing" of the anomaly, while in individuals with partial accretion of the pedipalpus and the first walking 
leg the anomaly became more pronounced. While in larvae three or four proximal joint were accreted, in nymphs II heterosymely extended also to the following fragment of the regenerating appendages. The regenerates with the remaining part of the complex were rigid and did not participate in the spiders' locomotion, and their bend towards the mouth cavity often impeded food intake. That is why the distal parts of the regenerates were often destroyed: after being punctured with the chelicerae they soon dried up (Fig. 14). After that the injured fragment of the appendage regenerated again. For that reason after successive moults changes in the structure of the regenerates were observed, consisting in simultaneous occurrence of fragments differing in age. The destroyed distal parts regenerated again and showed all the features of the first regenerate, while the remaining fragments were already in a later, more advanced development stage. On the other hand, in cases when the distal parts of the regenerates were not injured, the entire heterosymelic complexes were observed to develop after each moult. There were more setae on the regenerates (Fig. 15). In five cases small dentate claws were found on the free endings in nymph III stage. Twenty six individuals survived until nymph $\mathrm{V}$ stage.

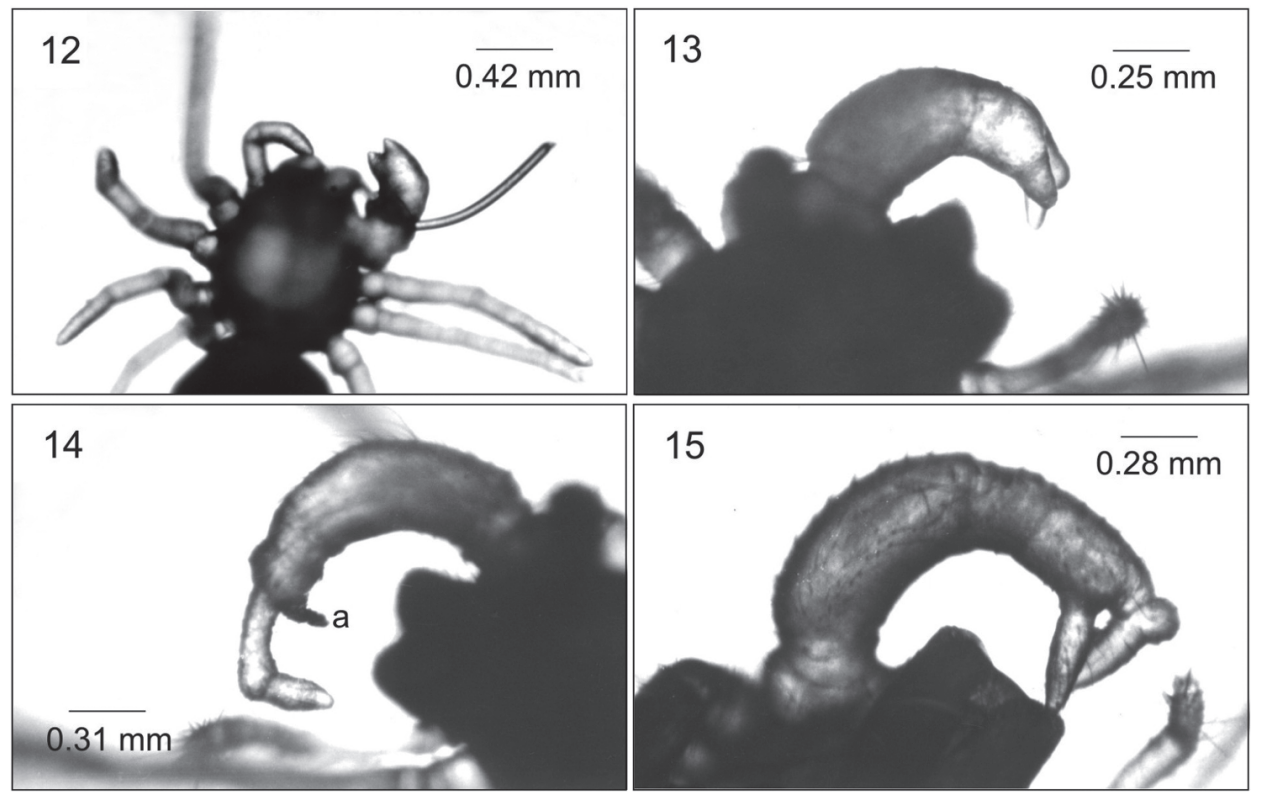

Figs 12-15. 12 - Heterosymelic Tegenaria atrica C.L.Koch larva with ligature in the area of coadunate femur joints of pedipalpus and walking appendage; 13 - First regenerate in heterosymelic Tegenaria atrica C.L.Koch nymph II with free endings in distal part; 14 - Bifurcate heterosymelic regenerate of pedipalpus and walking leg in nymph IV stage: a - dying part of appendage; 15 - Regenerate of heterosymelic pedipalpus and walking appendage at nymph III stage. 
Since all three larvae with complete heterosymely of the pedipalpus and the walking appendage died in ecdysis, only five individuals with comparatively shallow partial heterosymely remained in the control sample until the ending of the experiment. After each ecdysis the joints of the accreted appendages developed properly, there were more increasingly longer setae on them, and the lengths of the two accreted legs were comparable with those of the sister legs on the other side of the prosoma. In spite of the considerable limitation of the mobility of the entire heterosymelic complex the spiders moved around their webs fairly skilfully.

Out of 45 individuals selected from the teratological material for amputation ca $42 \%$ (19 individuals) died in the course of the experiment. For most of them the critical moment was the mere application of the ligature on the considerably thickened and elastic common part of the appendages, for the remaining it was the first and the second larval ecdysis. In the control sample the mortality was somewhat lower: ca $37 \%$.

\section{DISCUSION}

Tegenaria individuals with heterosymely of two walking appendages and with heterosymely of the pedipalpus and the first walking appendage were used for studies on the epimorphic capabilities of prosomal appendages. The choice of such deformities was induced in the first place by the structure and function of those appendages. It was assumed that regeneration of accreted appendages with the same seven-joint structure and similar equipment with structures of cuticular origin might proceed in a different way than regeneration of appendages with different morphological structures, since pedipalpi are much shorter appendages with six joints, and their function as cephalic appendages includes food intake. It was also assumed that the difference in the location of nerve ganglia directing the function of those appendages could be of some importance. According to the results of Mitmann's and Scholtz's (2003) studies conducted with the use of neurospecific markers, and confirmed by DAMEN at al. (1998) on the ground of the Hox genes expression formula, the pedipalpal ganglia from which nerves run to those appendages belong to tritocerebrum, i.e. to the brain, while the ganglia of the walking appendages together with the nerves constitute the subesophageal nerve mass. The question then arises if after amputation of a heterosymelic complex consisting of the pedipalpus and a walking leg all the above mentioned differences between those appendages will affect the direction and the rate of regeneration. That is why in one part of individuals selected for the experiment heterosymely affected two walking appendages, while in the other part it concerned two different prosomal appendages.

Amputation was carried out with the use of nylon thread ligatures, though other methods are known as well. Considering, however, the stress that affects the operated individuals, that method seemed the best. In spite of that it sometimes happened that as the ligatures were tightened the body covers were injured, which significantly increased the mortality in the course of the experi- 
ment. The time of amputation was also important. Since in the first 24 hours of life the cuticle is very delicate and even the slightest break of its continuity may imply considerable loss of hemolymph, the ligatures were applied only on the second day after the larvae left their egg and prelarval membranes. It was also necessary to take into account that the larval stage in this spider species is rather short, and under laboratory conditions it averages only six days ( $\mathrm{J}_{\text {ACUŃSKI }}$ et al., 1999). Early application of ligatures guaranteed a longer, and therefore more effective, process of wound scabbing. The location of the ligature on the thick elastic part of the heterosymelic complex resulted in the formation of irregularities in the form of nodules and small lenticular irregularities on the post-amputation surfaces. They appeared in the course of the first postlarval moult after the ligature with the rest of the appendage had been cast off. The nodules did not change in size in the periods between moults but after a time they changed colour to brown, which testified to their cuticular origin. Those considerably hardened structures did not seem to affect the course of epimorphosis, because they were thrown off together with the whole exuvium in the course of the following, second postlarval moult. After that, i.e. in nymphs II, the first morphologically visible effect of epimorphosis was observed in all the operated individuals. It may therefore be concluded that the drastic reduction in size of the body cavity by casting off some part of the appendage does not significantly affect the condition of the larvae. They can successfully undertake regeneration, the evidence being the reconstructed parts of legs.

The directions and rates of epimorphosis in the particular variants were different. In the first one, in which one free ending of a heterosymelic appendage was amputated, the efficiently progressing regeneration resulted in formation of the lost free part of the appendage. Nymph V stage (Table 1), when the regenerates together with remaining parts of the legs reached ca $99.63 \%$ length of their sister appendages on the opposite side of the prosoma, was regarded as one completing the epimorphic process. It can therefore be assumed that in spite of several proximal joints of appendages being accreted the capability for regeneration of their endings remains at the some level as in normal, properly developed jointed legs (Mikulska et al., 1975; JACUŃSKi et al., 1994).

Widely different effects of regeneration processes were observed after the amputation of much larger fragments of heterosymelic walking appendages. The regenerates in this variant had a twofold form. In a part of the spiders the regenerated appendage fragment retained its bifurcation. It was then still partial heterosymely, the only difference being that the common part of the complex became elongated at the expense of the free endings. The morphogenetic processes in that case resulted in deepening of the anomaly, which in the further course of the experiment did not change. In the remaining experimental individuals with partly accreted walking appendages there developed one homogeneous regenerate showing complete heterosymely. That was the maximum deepening of the anomaly. To sum up, the regeneration processes in that variant caused the original deformity to deepen. It can be assumed that the course of development of the regenerates was a specific way of reducing the bifurcation in the distal 
part, which could considerably facilitate the following ecdyses, since the bifurcation impedes the casting off of the old exuvium and obstructs the execution of the basic vital functions. The growth rate of the regenerates is a disputable matter. The fact that the regenerates did not reach the length of their normally developing sister appendages until nymph $\mathrm{V}$ stage when the observations were ended is not evidence of a slower course of epimorphosis. It may, however, indicate that it proceeded in a different way than in the previous variant of the experiment, as regeneration of two appendages certainly demanded a greater effort and energy input. Moreover, the progress of the morphogenetic process was additionally complicated by the fact that the accreted, common part of those appendages had also to regenerate, which might considerably protract the process.

The situation was different in the regeneration of an accreted pedipalpus and a walking leg. In that case, too, the regenerates together with old parts of the appendages did not reach the lengths of the sister appendages but that seemed to be caused by several factors. The most important factor affecting the progress of epimorphosis and the form of the regenerates were differences in jointing of the two appendages. Regardless the degree of the original anomaly (complete or partial heterosymely) the regenerates always had two free endings of different lengths and structures in their distal parts. The walking leg consists of seven joints, while the pedipalpus is much shorter, it has six joints and does not contain a metatarsus. That is why the absence of accretion of the distal parts of the regenerates resulted probably from the difference in jointing of those appendages, and in such anomalies as heterosymely or symely accretion of appendages occurs only between corresponding joints (JACUŃSKI, 1971). That difference undoubtedly impedes complete accretion of those appendages. However, the question a rises: why then is it possible for complete accretion of a walking leg with the pedipalpus to occur in the course of disturbed embryogenesis? This is probably related to the direction of the formation of the successive joints in the course of embryonic development and at the time of epimorphosis of the appendages. The shape of such heterosymelic complexes also depended on the length, jointing and equipment with structures of cuticular origin. This why they became archwise curved, and the distal endings came close to the mouth opening and were often destroyed by the chelicerae in the course of food intake. It was the main cause of the constantly renewed regeneration process in that place.

Regardless of the form of the regenerates in all the variants of the experiment it was possible to distinguish two development stages, the larval and the nymphal stage. The distinction was made based on such features as the number of joints and setae, the presence and shape of claws and the saturation of the cuticle with pigment. The absence of the first two stages in the development of the regenerates, i. e. of the embryonic and prelarval stage, described in detail by VACHON (1967) in Coelotes terrestris, could be explained only by the time of amputation. VACHON amputated appendages in the nymphal stage, while in the present experiment the larvae were operated on the second day after emergence 
from eggs. That part of postembryonic life is known to be very short, shorter than the following nymphal stages. With the nymph's age the duration of the period between successive moults increases, and the structure of the first and the following regenerates depends on the length of the intermoult period and on the quarter of the period in which the amputation was carried out. The dependence is simple: the longer the time between the amputation and the following moult the more advanced the regenerate's development after the moult. That is why all the four stages indicated by VACHON (1967) may but need not occur in the epimorphic process. The occurrence in Tegenaria (N I) of one development stage without a noticeable regenerate seems to be directly related to the very short larval period in which amputation was carried out. It was too short for any kind of regenerate to develop.

It follows from the above observations that regeneration in Tegenaria is a common phenomenon. It applies not only to properly developed appendages but also to those considerably deformed - heterosymelic ones. It proceeds with the same intensity in appendages differing in morphological structure and innervation. The development of such capability for regeneration together with the common autotomy of appendages can be considered to be a certain development strategy given by nature, which by obliterating teratological changes in appendages, unfavourable for their behaviour, increases the survival rate in spiders, and possibly in other arthropods.

\section{EPIMORFOZA ODNÓŻY HETEROSYMELICZNYCH U PAJĄKA TEGENARIA ATRICA C.L.KOCH}

\section{STRESZCZENIE}

Badania nad regeneracją epimorficzną przysadek przeprowadzono na larwach i nimfach pająka Tegenaria atrica C.L.Koch z heterosymelią (zrost wzdłużny odnóży leżących po tej samej stronie ciała) samych odnóży chodowych oraz odnóży chodowych z nogogłaszczkami. Wszystkie anomalie otrzymano poddając rozwijające się zarodki naprzemiennemu działaniu dwóch temperatur: 14 i $32^{\circ} \mathrm{C}$. Po amputacji fragmentów odnóży dotkniętych tym rodzajem anomalii zawsze występowały procesy regeneracyjne. Na podstawie charakterystycznych struktur zewnętrznych regenerujących członów ustalono fazy epimorfozy, których początek i koniec wyznaczały kolejne linienia. Stwierdzono różne typy regeneratów, których plan budowy anatomicznej do czasu zakończenia obserwacji zasadniczo nie ulegał dalszym zmianom.

\section{REFERENCES}

AgAR, W.E., 1930: A statistical study of regeneration in two species of Crustacea. J. Exp. Biol., 7: 349-369.

Bittner, G.D., 1973: Degeneration and regeneration in crustacean neuromuscular systems. Am. Zool., 13: 379-408.

Bonnet, P., 1930: La mue, l'autotomie et la régénération chez les araignées, avec une étude des Dolomédes d’Europe. Bull. Soc. Hist. Nat., Toulouse, 59: 237-700. 
Brock, R.E., Sмith, L.D., 1998: Recovery of claw size and function following autotomy in Cancer productus (Decapoda: Brachyura). Biol. Bull., 194: 53-62.

Clare, A.S., Costlow, D.J., Bedair, H.M, Lumb, G., 1992: Assessment of crab limb regeneration as an assay for developmental toxicity. Canadian Journal of Fisheries and Aquatic Sciences, 49: 1268-1273.

Cooper R.L., 1998: Development of sensory processes during limb regeneration adult cryfish. J. Exp. Biol., 201: 1745-1752.

Damen, W.G.M., Hausdorf M., Steyfarth, E.-A., Tautz, D., 1998: A conserved mode of head segmentation in arthropods revealed by the expression pattern of Hox genes in a spider. Proc. Nat. Acad. Sci., USA, 95: 10665-10670.

Demeusy, N., 1995: Quelques aspects de la régénération chez les Crustacés. Ann. Sci. Nat., Zool., Paris, 13 (16): 105-112.

Edwards, J. S., 1972: Limb loss and regeneration in two crabs: the king crab Paralithodes camtschatica and the tanner crab Chionoecetes bairdi. Acta Zool., 53: 105-112.

Fournier, B., 1973: Contribution à l' étude quantitative de la régénération des pattes chez l'embryon du phasme Carausius morosus Br. Archives de Zoologie Expérimentale \& Générale, 114: 627-652.

Friedrich, P., 1906: Regeneration der Beine und Autotomie bei Spinnen. Arch. EntwMech. Org., 20: 469-506.

Gabritschevsky, E., 1927: Experiments on colour changes and regeneration in the crabspider, Misumena vatia. J. Exp. Zool., 47: 251-266.

GABRItschevsKy, E., 1930: Les réductions régulatrices et les compensations hypertrophiques pedant l'ontogenése et la régénération de l'araignée Thomisus onustus. Bull. Biol. Fr. Belg., 64: 155-190.

Goss, R.J., 1969: Principles of regeneration. Academic Press, New York \& London, 287 pp.

Hopkins, P. M., 1982: Growth and regeneration patterns in the fiddler crab, Uca pugilator. Biol. Bull., 163: 301-319.

Hopkins, P.M., 1993: Regeneration of walking legs in the fiddler crab Uca pugilator. Am. Zool., 33: 348-356.

Hopkins, P.M., 1995: Effects of all-trans retinoic acid on regenerating limbs of the fiddler crab, Uca pugilator. J. Exp. Zool., 272: 455-463.

Hopkins, P.M., 2001: Limb regeneration in the fiddler crab, Uca pugilator: hormonal and growth factor control. Am. Zool., 41: 389-398.

JACUŃSKI, L., 1971: Temperature induced developmental monstrosities in Tegenaria atrica C.L.Koch (Araneae, Agelenidae). Zool. Pol., 21: 285-316.

JACUŃSKI, L., 1983: Zaburzenia w wewnętrznej metamerii wywołane eksperymentalnie u Tegenaria atrica C.L.Koch (Aranei, Agelenidae). Przegl. Zool., 2: 219-223.

Jacuński, L., Napiórkowska, T., Tesznar, L., 1999: Hodowla pająka Tegenaria atrica C.L.Koch. Przegl. Zool., (1-2): 111-116.

Jacuński, L., Wiśniewski, H., Templin, J., 1994: The epimorphosis of a walking leg in the early stages of postembryogeny in Tegenaria atrica C.L.KocH (Arachnidae, Agelenidae). Zesz. Nauk. WSP, Bydgoszcz, Stud. Przyr., 11: 135-163.

Juanes, F., Smith, L.D., 1995: The ecological consequences of limb damage and loss in decapod crustaceans: a review and prospectus. J.Exp. Mar. Biol. \& Ecol., 193: $197-223$.

Lakes, R., Mücke, A., 1989: Regeneration of the foreleg tibia and tarsi of Ephippiger ephippiger (Orthoptera: Tettigoniidae). J.Exp. Zool., 250: 176-187.

Locket, G.H., 1936: Regeneration in Arachnida. Nature, 138: 885-886.

Lumb, G., Clare, A.S., Costlow, J.D., 1991: Cheliped regeneration in the megalopa of the mud crab, Rhithropanopeus harrisii (Gould). Inv. Reprod. \& Devel., 20 (2): 87-96. 
Mc Vean, A., 1976: The incidence of autotomy in Carcinus maenas (L.). J. Exp. Mar. Biol. \& Ecol., 24: 177-187.

MikUlSKA, I., JACUŃSKI, L., 1977: The regulating processes after the amputation of teratologically changed appendages in Tegenaria atrica C.L.Koch (Araneae, Agelenidae). Zool. Polon., 26: 45-50.

Mikulska, I., Jacuński, L., Weychert, K., 1975: The regeneration of appendages in Tegenaria atrica C.L.Косн (Agelenidae, Araneae). Zool. Polon., 25: 99-110.

Mitmann, B., Scholtz, G., 2003: Development of the nervous system in the "head" of Limulus polyphemus (Chelicerata: Xiposura): morphological evidence for a correspondence between the segments of the chelicerae and of the (first) antennae of Mandibulata. Dev. Genes. Evol., 213: 9-17.

Mohrherr, C.J., 1987: Cheliped autotomy and limb regeneration in the east African fiddler crabs Uca lactea (De HaAn) and U. chlorophthalmus (H. Milne Edwards). J. Crust. Biol., 7: 302-307.

Mykles, D.L., 2001: Interactions between limb regeneration and molting in decapod crustaceans. Am. Zool., 41: 399-406.

Needham, A.E., 1965: Regeneration in the Arthropoda and its endocrine control. In V. Kirtosis and H.A.L. Trampusah (eds.), Regeneration in animals and related problems, North-Holl. Publ. Co., Amsterdam, 282-323.

Oppenheim, S., 1908: Regeneration und Autotomie bei Spinnen. Zool. Anz., 33: 56-60.

PenZlin, H., 1963: Über die Regeneration bei Schaben (Blattaria). I. Das Regenerationsvermögen und die Genese des Regenerates. Arch. EntwMech. Organ., 154: 434-465.

Randall, J.B., 1981: Regeneration and autotomy exhibited by the black widow spider, Latrodectus variolus WalcKenAer. Wilhelm Roux Arch. Dev. Biol., 190: 230-232.

Read, A.T., Govind, C.K., 1998: Cell types in regenerating claws of the snapping shrimp, Alpheus heterochelis. Can. J. Zool., 76: 1080-1090.

Reichman, O.J., 1984: Evolution of regeneration capabilities. Am. Nat., 123 (6): 752-763.

Rотн, V.D., Rотн, B.M., 1984: A revive of appendotomy in spiders and other arachnids. Bull. Br. Arachnol. Soc., 6: 137-146.

Ruchland, M., 1976: Die neuromuskuläre Organisation normaler und regenerierter Laufbeine einer Vogelspinne (Dugesiella hentzi CH., Orthognatha, Aviculariidae). Dessertation, Universität Konstanz, West Germany.

SAVORY, T.H., 1936: Regeneration in Arachnida. Nature, 138: 550.

Sмith, L.D., 1990: Patterns of limb loss in the blue crab, Callinectes sapidus Rathbun, and the effects of autotomy on growth. Bull. Mar. Sci, 46 (1): 23-36.

Sмith, L.D., 1992: The impact of limb autotomy on mate competition in blue crabs Callinectes sapidus Rathbun. Oecologia, 89: 494-501.

VACHON, M., 1967: Nouvelles remarques sur la régénération des pattes chez l'araiginée Celotes terrestris Wid. (Agelenidae). Bull. Soc. Zool. Fr., 92: 417-428.

Vollrath, F., 1990: Leg regeneration in web spiders and its implications for orb weaver phylogeny. Bull. Br. Arachnol. Soc., 8 (6): 177-184.

Weiss, O., 1907: Regeneration und Autotomie bei der Wasserspine (Argyroneta aquatica C1.). Arch. EntwMech. Org. 23: 643-645.

Wood, F.D., 1926: Autotomy in Arachnida. J. Morphol., 42: 143-195. 